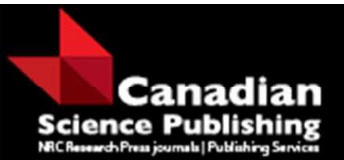

Canadian Journal of Forest Research

Revue canadienne de recherche forestière

\title{
An investigation into the contrasting growth response of lodgepole pine and white spruce to harvest-related soil disturbance
}

\begin{tabular}{|r|l|}
\hline Journal: & Canadian Journal of Forest Research \\
\hline Manuscript ID & cjfr-2016-0386.R1 \\
\hline Manuscript Type: & Article \\
\hline Complete List of Authors: & $\begin{array}{l}\text { Kranabetter, John Marty; British Columbia Ministry of Forests and Range } \\
\text { Dube, Stephane; College of New Caledonia } \\
\text { Lilles, Erica; British Columbia Ministry of Forests Lands and Natural } \\
\text { Resource Operations }\end{array}$ \\
\hline Keyword: & compaction, whole-tree harvest, 13C, Pinus contorta, Picea glauca \\
\hline \multicolumn{2}{|c}{} \\
\hline
\end{tabular}

\section{SCHOLARONE ${ }^{\text {Tw }}$}

Manuscripts 
An investigation into the contrasting growth response of lodgepole pine and white spruce to harvest-related soil disturbance

9 10 J.M. Kranabetter ${ }^{1}$, S. Dube ${ }^{2}$ and E.B. Lilles ${ }^{3}$

13 P.O. Box 9536, Stn Prov Govt, Victoria, B.C., Canada V8W 9C4

Tel: 1250 952-4172, Fax: 1250 952-4119 


\section{Abstract}

Losses in forest productivity through poor soil management are typically evaluated by changes

26 in crop production, but conflicting growth responses among co-occurring species can challenge criteria

27 for sustainability. In this study we evaluate species response to compaction and organic matter removal

28 by contrasting the growth and foliar attributes at age 20 of lodgepole pine (Pinus contorta Dougl. ex

29 Loud.) and hybrid white spruce (Picea glauca $\mathrm{x}$ engelmannii [Moench] Voss) in sub-boreal forests of

30 central British Columbia. Bole volume increment was stable for lodgepole pine, averaging a $6 \%$

31 difference across treatments. White spruce, in contrast, often had large growth increases on forest

32 floor retained - compacted plots (average of 63\% gain), but reductions in productivity on the forest floor

33 removed - compacted plots ( $40 \%$ decline). Foliar nitrogen concentrations converged across treatments

34 for both species, despite the removal of over $50 \%$ of the site $\mathrm{N}$ capital. Some key differences in species

35 traits were suggested by foliar $\delta^{15} \mathrm{~N}$, attributed to deeper rooting of pine, and foliar $\delta^{13} \mathrm{C}$, indicating

36 possibly higher $\mathrm{CO}_{2}$ assimilation potential for spruce. The implication is that standard metrics of

37 sustainable forestry are contingent upon tree autecology, and that comprehensive assessments of land

38 management require a measure of collective species response.

39 Keywords: compaction, whole-tree harvest, ${ }^{13} \mathrm{C}$, Pinus contorta, Picea glauca 


\section{Introduction}

The post-harvest maintenance of soil productivity is a widely accepted and fundamental

42 principle of sustainable forestry (Powers et al. 1999, Schoenholtz et al. 2000, Moffat 2003), and the

43 impetus behind many studies of management issues such as biomass harvesting and heavy machine

44 traffic (Thiffault et al. 2011, Ampoorter et al. 2011, Achat et al. 2015). Soil productivity has been

45 primarily defined and quantified by the production of crops over a unit of time (i.e., net primary

productivity, $\mathrm{kg} \mathrm{ha}^{-1} \mathrm{yr}^{-1}$ ), where any changes in tree growth can be attributed to differences in soil

47 conditions, rather than silvicultural influences such as regeneration delay, stand tending, or removal of

48 competing vegetation (Morris 1997). While a number of key soil properties that support crop

production can be fairly readily measured, particularly nutrient and water availability (Paré et al. 2002,

Duchesne and Houle 2008, Brandtberg and Olsson 2012), assessments of management impacts are

51 often based ultimately on tree growth (e.g., Kabzems 2012, Fleming et al. 2014), with a suggested

52 threshold of 15\% productivity loss as defining detrimental soil disturbance (Powers et al. 1999). Other

53 important functions of soils, such as the maintenance of site hydrology, provision of biotic habitat, and

54 sequestration of carbon are acknowledged (Moffat 2003, Burger et al. 2008, Scott et al. 2014), but along

55 with the expressed goal of nondeclining trends in forest productivity over multiple rotations (Nambiar

56 1996).

Inherent site productivity varies widely depending upon abiotic features, including climate, soil

58 parent materials, and topography. The productive capacity of a soil may be altered both positively and

59 negatively by management activities, particularly harvest-related soil disturbances. Two key changes to

60 soils include reductions in soil porosity (compaction) and removal of site organic matter (OM), and

61 recognition of these risks to soil productivity prompted a large, co-ordinated research effort to quantify

62 these combined disturbance effects on forest plantations (the Long-term Soil Productivity study [LTSP];

63 Powers 2006). Synthesis of study results up to year 10 post-treatment have not found evidence of 
64

65

66

67

68

69

70

71

72

73

74

75

76

77

78

79

80

81

82

83

84

85

86

87

consistent, negative effects of site organic matter removal or compaction on tree growth, but experimental outcomes have varied depending on site vulnerability (defined in part by soil texture and mineralogy) and tree species (Powers et al. 2005, Ponder et al. 2012). In some circumstances the autecology of a tree species might explain unique responses to compaction or organic matter removal, such as how the regeneration success of aspen (Populus tremuloides Michx.) depends upon the timing of soil disturbance (Stone and Kabzems 2002). With other tree species, however, the mechanisms for a diverging growth response are more obscure, and could involve a variety of species traits, including rooting patterns, nutritional demands, drought or frost tolerance, and mycorrhizal associations (Ponder et al. 2012). There are also some uncertainties as to whether these species effects might only be ephemeral, with some convergence in biomass production as saplings more fully accommodate to disturbed site conditions over time (Heninger et al. 2002, Egnell 2011). Sustainable production of diverse forests is a key management objective in many jurisdictions, making it important to better define the mechanisms behind tree species response to harvest-related soil disturbance, and to confirm if these effects persist past the establishment phase of a forest rotation.

Lodgepole pine (Pinus contorta) and hybrid white spruce (Picea glauca $\mathrm{x}$ engelmannii) are native conifer species widely utilized in reforestation throughout central and northern British Columbia (Canada). Both species have comparable growth potential (site indices at 50 years of approximately 19 m) on mesic sites (Wang 1998), with an expected rotation age of 80 years, although lodgepole pine has much greater initial growth rates than white spruce (Eis et al. 1982). Kranabetter et al. (2006), in a LTSP trial of 10 years in duration, described how white spruce growth declined under severe soil disturbances (forest floor removed and compacted mineral soil), in contrast to lodgepole pine, making it difficult to demonstrate unequivocal losses in site productivity. Large differences in foliar $\mathrm{N}$ concentrations between these two species indicated discrepancies in $\mathrm{N}$ acquisition as a possible mechanism leading to a diverging growth response. Another factor in species response to soil disturbance may be related to 
water use and photosynthetic capacity (Gomez et al. 2002b, Choi et al. 2005), a potentially important difference among tree species given the sometimes beneficial increase in water-holding capacity found with soil compaction (Fleming et al. 1998, Brais 2001, Gomez et al. 2002a, Ares et al. 2005). Commercial forestry throughout the northern hemisphere use related species of pine and spruce (e.g., Thiffault et al. 2007, Helmisaari et al. 2011), each perhaps with similar autecology to $P$. contorta and $P$. glauca, so a better understanding of long-term response to harvest-related soil disturbances by these conifer species may prove relevant to vast areas of managed forests.

In this study we present the 20 year results from OM removal and compaction treatments in the Sub-Boreal Spruce zone of central British Columbia. We examine the most recent volume increment (years 15-20) of lodgepole pine and hybrid white spruce to test whether initial contrasting trends in productivity (Kranabetter et al. 2006) have converged over time. Foliar nutrient concentrations and natural isotope $\left({ }^{13} \mathrm{C}\right.$ and ${ }^{15} \mathrm{~N}$ ) abundance, which integrate plant responses to resource gradients (Dawson et al. 2002), were examined for evidence of ecological traits separating the growth responses of these conifer species to soil disturbance (Gomez et al. 2002b, Choi et al. 2005, Tan et al. 2006). The objectives of our study were to 1) establish the extent of productivity changes due to organic matter removal and soil compaction after 20 years in the Sub-Boreal Spruce zone; 2) test whether co-occurring conifer species respond differently to harvest-related soil disturbance via growth rates and nutrition; and 3) elucidate possible mechanisms related to species autecology that would explain differences in treatment response. Our hypotheses at the onset of the LTSP study were that losses in site organic matter and reductions in soil porosity would be detrimental to forest soils (i.e., $>15 \%$ decline in productivity), with parallel losses in productivity between conifer species.

\section{Materials and Methods}

Site Descriptions 
The LTSP installations in central British Columbia are located in the Sub-boreal Spruce

112 biogeoclimatic zone (SBS), characterized by cold, snowy winters and relatively warm, moist and short

113 summers (Meidinger and Pojar 1991). Three subzones were selected as sites (blocks) to replicate the

114 LTSP experiment across a relative range of climatic conditions encompassed by SBS forests. Climate

115 variables of mean annual temperature (MAT), precipitation (MAP) and heat:moisture index (AH:M =

$116[\mathrm{MAT}+10] /[\mathrm{MAP} / 1000])$ were obtained for the 2001-2010 decade at each study site by querying

117 ClimateWNA (Wang et al. 2006) with latitude, longitude and elevation. The three test sites include the

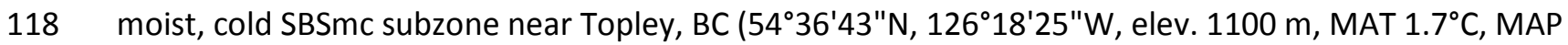

$119614 \mathrm{~mm}, \mathrm{AH}: \mathrm{M} 18.2)$; the wet, cool SBSwk near Prince George, BC (54²1'57"N, $122^{\circ} 36^{\prime} 48^{\prime \prime} \mathrm{W}$, elev. 785

120

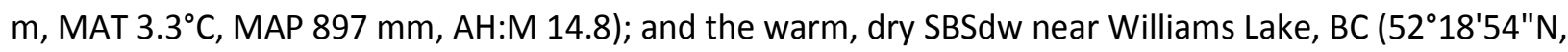

121 121 $54^{\circ} 51^{\prime \prime} \mathrm{W}$, elev. $1050 \mathrm{~m}$, MAT 3.8 ${ }^{\circ} \mathrm{C}$, MAP $559 \mathrm{~mm}, \mathrm{AH}: \mathrm{M}$ 24.7). The sites are located within an

122 approx. $200 \mathrm{~km}$ radius. Each site has deep, moderately well-drained to well-drained soils derived from

123 ablation till, with textures ranging from sandy loam to loam (SBSmc 52\% sand, 27\% silt, 21\% clay; SBSwk

$12444 \%$ sand, 40\% silt, 16\% clay; SBSdw 56\% sand, 35\% silt, 9\% clay; Krzic et al. 2004), up to 40\% coarse

125 fragments, and mor humus forms approximately $7 \mathrm{~cm}$ thick. Sites were level (SBSdw), or had slopes

126 ranging from 2-12\%. Preharvest stands were 112-140 years old and comprised predominantly of

127 subalpine fir (Abies lasiocarpa [Hook.] Nutt), hybrid white spruce and lodgepole pine. Site indices, based

128 on preharvest stands, averaged $17.5 \mathrm{~m}$ at $50 \mathrm{yrs}$.

129 Experimental Design

Each LTSP site has nine plots ( $40 \times 70 \mathrm{~m}$ each), arranged in a factorial combination of three

131 organic matter removal treatments:

132 OM1 - Stem (boles) only removed, logging slash retained;

133 OM2 - Stems and crowns removed (whole-tree harvesting);

134 OM3 - Whole-tree and forest floor removed (scalped to mineral soil); 
and three soil compaction treatments:

$$
\text { CO - No compaction; }
$$

C1 - Light compaction (2 cm impression into mineral soil);

C2 - Heavy compaction (4 cm impression).

Each site was hand-felled in the winter to minimize soil disturbance. Logging slash was removed by hand, and forest floors were extracted with an excavator and bucket attachment, with as little mineral soil removal as possible. Soil compaction to the required depths was done with an excavatormounted hydraulic tamping plate. On the bole-only removal treatment, the logging slash was piled into rows to allow compaction without impressing the slash into the soil and then respread. The treatment plots were split $(40 \times 35 \mathrm{~m})$ and planted with copper-treated 1+0 211 PSB (polystyro blocks) lodgepole pine or untreated 2+0 415 PSB hybrid white spruce. Local provenances were used for planting stock, and seedlings were planted at $2.5 \times 2.5 \mathrm{~m}$ spacing in the spring following treatment installation. In the centre portion of each split-plot we tagged 100 seedlings ( $10 \times 10$ rows) for remeasurement, with the outer two rows providing a buffer on all sides to minimize edge effects. Vegetation surrounding the seedlings was clipped and removed up to a $50 \mathrm{~cm}$ radius for the first 5 years to reduce competition effects. Any seedling mortality during the course of the study was not replaced. The experimental installation was completed in 1993 for the SBSwk and SBSmc sites, and in 1994 for the SBSdw site. Some key site variables related to the treatments were described previously (Sanborn et al. 2000, Kranabetter and Chapman 2004, Kranabetter et al. 2006) and summarized here: logging slash averaged 34.6 tonnes $\mathrm{ha}^{-1}$, equivalent to $58 \mathrm{~kg} \mathrm{~N} \mathrm{ha}^{-1}$; forest floor mass averaged 65 tonnes ha ${ }^{-1}$, equivalent to $815 \mathrm{~kg} \mathrm{~N} \mathrm{ha}^{-1}$; mineral soil N (to a $20 \mathrm{~cm}$ depth) averaged $1664 \mathrm{~kg} \mathrm{ha}^{-1}$; pre-treatment bulk density ( $<2 \mathrm{~mm}$ fraction) averaged $1.07 \mathrm{~g} \mathrm{~cm}^{-3}$, and increased to $1.42 \mathrm{~g} \mathrm{~cm}^{-3}$ with light compaction and $1.49 \mathrm{~g} \mathrm{~cm}^{-3}$ with heavy compaction (no statistical difference in bulk density between $\mathrm{C} 1$ and $\mathrm{C} 2$ treatments). Maximum bulk density, which is the theoretically highest compactability value based on 
159

160

161

162

163

164

165

166

167

168

169

170

171

172

173

174

175

176

177

178

179

180

181

182

post-harvest mineral soil \% C content (Krzic et al. 2004), averaged $1.61 \mathrm{~g} \mathrm{~cm}^{-3}$ for SBSdw, $1.55 \mathrm{~g} \mathrm{~cm}^{-3}$ for SBSwk, and $1.51 \mathrm{~g} \mathrm{~cm}^{-3}$ for SBSmc. Daily average mineral soil temperature $(10 \mathrm{~cm}$ depth) over the growing season increased by $1^{\circ} \mathrm{C}$ to $3^{\circ} \mathrm{C}$ with whole-tree removal and scalping, respectively, and by approx. $0.5^{\circ} \mathrm{C}$ with compaction.

Tree and soil measures

Tree survival, height and diameter (at root collar initially, then at $1.3 \mathrm{~m}$ as trees reached pole size) were measured every 5 years (up to 20 years post-treatment) and bole volume was calculated with juvenile taper equations for each species (Kovats 1977). Differences in average bole volume by split-plot were determined between years 15 and 20 to derive the most recent growth increment. Volume increment was presented as a percent change to standardize treatment responses between species and sites (Thiffault et al. 2011). The percent change was calculated as the difference between each treatment plot from the least disturbed (OM1C0) treatment (e.g., [OM2C0-OM1C0]/OM1C0 x 100). Site index (metres at $50 \mathrm{yrs}$ ) was calculated from tree height and age using Forests Site Tools 3.3 (B.C. Ministry of Forests 2004).

All soil sampling took place within the central portion of each split-plot (the $10 \times 10$ rows of tagged trees). Chemical properties of forest floors and mineral soils (to $20 \mathrm{~cm}$ depth) were collected preharvest and at years 1, 5, 10, 15 and 20 post-treatment. Up to year 5, 25 subsamples were taken randomly throughout a plot and bulked into five samples, after which we collected three bulked subsamples of five sampling points (15 in total) per species split-plot. Soils were air-dried and sieved ( 2 $\mathrm{mm}$ ) for analysis. Soil bulk density (BD) was determined by excavation to $20 \mathrm{~cm}$ at pre-harvest and years $1,5,10$ and 20 , starting with 10 random points per plot and then, by year 5 , five random points per splitplot. Fine fraction $B D(<2 \mathrm{~mm})$ was calculated with an assumed specific gravity of the coarse fragments of $2.65 \mathrm{~g} \mathrm{~cm}^{-3}$, and relative bulk density (RBD) was determined as BD/Maximum Bulk Density (Zhao et al. 2010). Starting in year 5 post-treatment, foliar sampling was undertaken at 5 year intervals for each 
183

184

185

186

187

188

189

190

191

192

193

194

195

196

197

198

199

200

201

202

203

204

205

206 species, with single bulked samples (10 trees combined) initially that was increased to three bulked subsamples (15 trees in total) per split-plot in years 15 and 20. Foliar samples were taken from the current year's growth in the top quarter of each tree in the fall (September-October) when growth had ceased. In 2015 (22 years post-treatment), soil moisture of the mineral soil $(0-20 \mathrm{~cm}$ ) was measured every three weeks (mid-May to mid-September) at the SBSmc site. A soil auger was used to extract five cores per split-plot, and these were bulked into one sample for gravimetric moisture determination $\left(105^{\circ} \mathrm{C}\right.$ for 24 hours) of the fine fraction $(<2 \mathrm{~mm})$.

Foliar mass was determined on 100 needles, and foliar nutrient concentrations determined by dry combustion with a Leco CHN-600 analyzer (LECO Corp. St. Joseph, MI). Macronutrients were analyzed by inductively coupled plasma-atomic emission spectroscopy following microwave digestion.

Mineralizable $\mathrm{N}$ concentrations of soils were measured via a 2-week anaerobic lab incubation (Kalra and Maynard 1991). The relative abundance of ${ }^{13} \mathrm{C}$ and ${ }^{15} \mathrm{~N}$, reported as $\delta{ }^{13} \mathrm{C}_{\mathrm{vpdb}}$ and $\delta{ }^{15} \mathrm{~N}_{\text {air }}$ respectively, was determined on approximately $5 \mathrm{mg}$ of finely milled, oven dry $\left(70^{\circ} \mathrm{C}\right)$ foliage and soils using a Flash 2000 elemental analyzer coupled to a ConFlo IV interface and DELTA Advantage isotope ratio mass spectrometer (all instruments Thermo Fisher Scientific, Waltham, MA). Instrument calibration was performed using certified reference materials EMA-P2 $\left(\delta^{13} C_{v p d b}-28.19 \%\right.$, $\delta^{15} N_{\text {air }}-1.57 \%$ ), Sorghum Flour B2159 $\left(\delta^{13} \mathrm{C}_{\mathrm{vpdb}}-13.68 \%, \delta^{15} \mathrm{~N}_{\text {air }}-1.58 \%\right.$ ) and USGS40 $\left(\delta^{13} \mathrm{C}_{\mathrm{vpdb}}-26.39 \%\right.$, $\delta^{15} \mathrm{~N}_{\text {air }}-4.52 \%$ o. Reference materials EMA-P2 and Sorghum Flour purchased from Elemental Microanalysis Ltd, Okehampton, UK, traceable to isotope standards IAEA-CH-6 and IAEA-N-1. USGS40 purchased from National Institute of Standards and Technology (NIST), USDA. All reported values were calculated using Isodat3.0 gas isotope ratio MS software (Thermo Fisher Scientific) and subject to post-run two point linear normalization (Paul et al. 2007) to correct for instrument drift and changes in calibration gas. Foliar $\delta^{13} \mathrm{C}$ was tested as absolute values and in relation to the least disturbed (OM1C0) treatment (e.g., $\left.\Delta \delta^{13} \mathrm{C}=\mathrm{OM} 2 \mathrm{CO}-\mathrm{OM} 1 \mathrm{CO}\right)$. Statistics 
The experiment is a randomized block split-plot design. The main-plot factors (OM and Comp)

208

209

210

211

212

213

214

215

216

217

218

219

220

221

222

223

224

225

226

227

228

229

230

are arranged as a full factorial design replicated in three blocks (sites), with species (pine and spruce) as the split-plot factor. For foliar and growth data, subsamples and individual trees were averaged beforehand, yielding a single value for each combination of site/OM/Comp/species. For soil data (chemistry and bulk density), where species split-plot was not used in early sampling, we focus on OM and Comp effects by averaging subsamples for each combination of site/OM/Comp.

Data from year 20 (the most recent sampling) were modelled as randomized block split-plot design using the Mixed Procedure (Method=REML) in SAS (SAS Institute 2011). Both site and the pooled main-plot error term (site $\times \mathrm{OM} \times$ Comp) were handled as random effects. All model assumptions were assessed graphically. For example, overall model fit and the additivity assumption (Montgomery 2008) were examined by plotting the observed volume increment versus their model predicted value to ensure a relationship close to 1:1 (i.e. the model fit well to the data). Survival (per 100 tree split-plot) was modelled using an overdispersed generalized linear mixed model (GLMM) via Proc Glimmix in SAS (SAS Institute 2011). The model included the same terms as those used for the Mixed Procedure (OM/Comp/Species), but here the distribution (conditional on the random effects) was assumed to be binomial.

Multi-year data of plot attributes were fitted to a repeated measures extension of the Mixed Procedure model. In the case of repeated foliar sampling, year was handled as a split split-plot factor, site $\mathrm{x}$ species $\mathrm{x} \mathrm{OM} \times$ Comp was incorporated as an additional random factor, and the covariance of each subject (site $\mathrm{x}$ species $\times$ OM $\times$ Comp) was modelled as a generalized ar(1) process with unequal time steps (e.g. sp[pow][year] in Proc Mixed; SAS Institute 2011). For soil chemistry and bulk density we removed the species factor from the repeated measures model as the split-plot was not designated in the early years of post-treatment sampling. Statistical significance was set at $p<0.10$ in recognition of the inherent variability associated with field studies. 
The relationships between tree productivity (volume) and foliar traits were tested by step-wise

232 regression using a general linear model (GLM) with type III sums of squares (SAS Institute 2011). Site,

233 species and either foliar $\mathrm{N} \%$ or $\delta^{13} \mathrm{C}$ were tested with a full set of interactions (e.g., site $\mathrm{x}$ species $\mathrm{x}$ N\%),

234 and then refitted without the three- or two-way interactions if these terms were insignificant.

235 Results

236 Soil properties

The focus of this element of our study is species growth response to harvest-related soil disturbances, and so we present select post-treatment soils data here to define key parameters of the

239 study sites. The removal of forest floor was still evident 20 years post-treatment, with a high percentage (approx. 75\%) of mineral soil exposure and little humus accumulation during this time. Post-

241 treatment bulk density of the uncompacted soils averaged $1.19 \mathrm{~g} \mathrm{~cm}^{-3}$ (SE 0.016) up to year 20,

242 significantly less dense than light $\left(1.37[0.017] \mathrm{g} \mathrm{cm}^{-3}\right)$ and heavy $\left(1.32[0.018] \mathrm{g} \mathrm{cm}^{-3}\right)$ compaction

243 treatments, respectively $(p=0.01)$. This increase in soil bulk density was equivalent, on average, to a 244 relative bulk density of 0.86 across the compaction treatments. We found a marginal reduction $(p=$ $2450.08)$ in mineralizable $\mathrm{N}$ of the mineral soils $(0-20 \mathrm{~cm})$ with organic matter removal $(\mathrm{OM} 1=23.0$ [SE $2460.81] \mathrm{mg} \mathrm{kg}^{-1}, \mathrm{OM} 2=26.3[1.28] \mathrm{mg} \mathrm{kg}^{-1}$, and $\mathrm{OM} 3=17.9[0.60] \mathrm{mg} \mathrm{kg}^{-1}$ ) over the post-treatment period, 247 but no effect of compaction $(p=0.49)$. Forest floor mineralizable N (OM1 and OM2 only) was not 248 affected by the treatments ( $p$ values for $\mathrm{OM}=0.79$, Comp $=0.83$ ). Bulk soil $\delta^{15} \mathrm{~N}$ averaged $4.44 \%$ (SE $2490.16)$ for mineral soil and $0.54 \%$ o $(0.24)$ for forest floor at 20 years post-treatment. Differences in soil 250 moisture content over the 2015 growing season, measured at the SBSmc site, were most pronounced 251 with forest floor removal, reaching a 50\% decline at mid-July in comparison to the plots with forest floor 252 retained (Fig. 1).

253 Tree response 
Lodgepole pine was almost twice as tall as white spruce at year 20 , on average, with heights of

6.6 (SE 0.3) $\mathrm{m}$ and $3.3(0.3) \mathrm{m}$, respectively (Table 1). Wide differences in inherent productivity among the three sites were also evident, with the largest trees at the SBSwk site (average pine and spruce height of 8.4 [SE 0.2] $\mathrm{m}$ and 4.7 [0.2] $\mathrm{m}$, respectively), followed by SBSmc (pine and spruce heights of 6.4 [0.07] and 3.7 [0.3] m, respectively), and the SBSdw site (pine and spruce heights of 4.9 [0.1] $\mathrm{m}$ and 1.6 [0.1] $\mathrm{m}$, respectively). Site index (at 50 years) estimates on the least disturbed (OM1C0) plots predict fairly even growth trajectories between species, with an average of $19.4 \mathrm{~m}$ (pine) and $19.0 \mathrm{~m}$ (spruce) at SBSwk, $15.6 \mathrm{~m}$ (pine) and $16.2 \mathrm{~m}$ (spruce) at SBSmc, and $13.8 \mathrm{~m}$ (pine) and $9.0 \mathrm{~m}$ (spruce) at SBSdw. Plots were well stocked through year 20 for both species, averaging 89\% (SE 1.2) survival for pine and $90 \%$ (2.1) for spruce, with no effect of soil disturbance on mortality (Table 2). Bole volume increment between years 15 and 20 was relatively stable for lodgepole pine, averaging a 6\% difference across the treatments in relation to OM1C0 (Fig. 2). White spruce, in contrast, had much greater amplitude in volume increment, resulting in both Species $\times \mathrm{OM}$ and Species $\times \mathrm{OM} \times$ Comp interactions (Table 2). Spruce often had growth increases on forest floor retained - compacted plots (average of $63 \%$ [SE 17] gain) but reductions in productivity on the forest floor removed-compacted plots (average of $40 \%$ [8] decline) (Fig. 2).

Over the first two post-treatment decades foliar $\mathrm{N}$ concentrations of spruce had fluctuated

271 more broadly than pine (Species $\times$ Year $p<0.001$ ), with a large decline after year 5 that partially

272 recovered over the subsequent 10 years (Fig. 3). Some early differences between OM treatments in 273 foliar N\% at year 5 were not sustained over time (repeated measures $p$ values; $\mathrm{OM}=0.64$, Compaction $=$ 2740.45 , and $\mathrm{OM} \times$ Comp $=0.45)$, nor did we detect any significant species $\mathrm{x}$ treatment interactions

275 (Species $\times$ OM $p=0.56$, Species $\times$ Comp $=0.99$, Species $\times \mathrm{OM} \times$ Comp $=0.58$ ). At year 20, foliar $\mathrm{N}$ concentrations were significantly greater for lodgepole pine (mean $=1.11 \%$ [SE 0.03]) than white spruce

$277(1.04 \%[0.01])$, with no effects of soil disturbance treatments (Table 2). Foliar $\delta^{15} \mathrm{~N}$ values differed 
278

279

280

281

282

283

284

285

286

287

288

289

290

291

292

294

295

296

297

298

299

300

among species as well, with pine significantly less depleted on average than spruce (mean $=-2.24 \%$ [ [SE 0.18 ] and -3.71\%o [0.19], respectively) (Table 2, Fig. 4). Foliar $\delta^{15} \mathrm{~N}$ values also differed significantly among OM treatments, becoming less depleted with full organic matter removal (Table 2, Fig. 4). Other foliar macronutrient concentrations such as $\mathrm{P}, \mathrm{Ca}$ and $\mathrm{Mg}$, along with needle mass, differed between tree species but were also unaffected by the disturbance treatments ( Table 3). Some positive effects of $\mathrm{OM}$ removal and compaction were found for foliar $\mathrm{S}$ and $\mathrm{K}$ concentrations, although the increase was < 10\% (Supplemental Figure).

The natural abundance of $\delta^{13} \mathrm{C}$ in year 20 foliage was marginally different among $\mathrm{OM}$ treatments $(p=0.09)$, with values of $-26.36 \%$ o (SE 0.22$),-26.22 \%$ (0.23), and $-26.65 \%$ o (0.18) for bole-only, wholetree harvest, and forest floor removal plots, respectively. A test of $\Delta \delta^{13} \mathrm{C}$ (in relation to OM1C0) to standardize site differences revealed stronger effects of OM removal and tree species on C discrimination (Table 2, Fig. 5). $\delta^{13} \mathrm{C}$ became more negative with forest floor removal, as noted previously, while pine had more consistent depletion in ${ }^{13} \mathrm{C}$ on average than spruce, particularly where forest floors were retained (mean $\Delta \delta^{13} \mathrm{C}=-0.17 \%$ [SE 0.09] and $0.30 \%$ [0.09], respectively, for OM1 and $\mathrm{OM} 2$ treatments combined) (Fig. 5).

The relationship between tree volume and foliar attributes related to photosynthetic capacity (foliar $\left.\mathrm{N} \%, \delta^{13} \mathrm{C}\right)$ were not consistent between tree species. A species interaction with $\delta^{13} \mathrm{C}(p=0.015)$ was caused by a negative slope with lodgepole pine and tree volume, in contrast to a positive slope with white spruce, at least for two of the three sites (Fig. 6). Foliar N\% did not have a similar species interaction $(p=0.20)$, nor did it relate overall with volume $(p=0.76)$. There was significant covariation between foliar N\% and $\delta^{13} \mathrm{C}$ at the SBSwk site $(p=0.035)$, but not at the SBSmc $(p=0.59)$ or SBSdw $(p=$ $0.40)$ sites.

\section{Discussion}


Organic matter removal and soil compaction effects on productivity, both negative and positive,

302 were apparent 20 years post-treatment for white spruce, but not for lodgepole pine. Harvest-related

303 soil disturbance effects on crop production, based on a 15\% threshold (Powers et al. 1999), could

304 therefore be interpreted in this trial as simultaneously positive, negative, or of no consequence,

305 depending upon tree species. While the lack of consistency in growth response may be a challenge in

306 crafting non-specific guidelines on best management practices (Page-Dumroese et al. 2000, Curran et al.

307 2005), it also reflects important aspects of co-occurring species autecology in boreal ecosystems.

One of the stronger treatment effects was the full removal of site organic matter (whole-tree

309 harvest and forest floor scalping; OM3), as indicated by the reductions in soil moisture and mineralizable

310 N. Compaction of these scalped soils had a particularly detrimental effect on spruce productivity

311 through 20 years, estimated at a $40 \%$ reduction in volume increment. Lodgepole pine, however, was

312 more tolerant of these compacted soils, as evident by the neutral response to $\mathrm{OM} 3 \mathrm{C} 1$ and $\mathrm{OM} 3 \mathrm{C} 2$

313 treatments, which may reflect the more robust development of vertical roots with pine as suggested by

314 Zhao et al. (2010). Compacted mineral soils with an intact forest floor (OM1 and OM2), on the other

315 hand, were often beneficial to spruce growth (10 of the 12 compacted-forest floor plots had increased

316 spruce productivity, with 6 plots $>90 \%$ gains), despite an RBD $>0.8$, possibly because the mulch layer

317 minimized evaporative loss of water and the onset of root-restricting soil strength (Bulmer and Simpson

318 2005). Similar gains in tree growth with compaction have been noted previously over the LTSP network,

319 and generally attributed to improved soil temperature and moisture storage capacity (Ponder et al.

320 2012). Our results are in contrast, however, to a negative growth response of white spruce with

321 compaction on boreal LTSP sites in northeast British Columbia (Tan et al. 2006, Kabzems 2012), perhaps

322 due to finer soil texture and flat topography that can lead to prolonged soil saturation and the onset of

323 anoxic conditions (Startsev and McNabb 2009). One question to be evaluated as stands mature will be 
324 whether rooting in compacted soils is limited to surface organic horizons and shallow mineral layers

325 such that available rooting volume eventually constrains tree growth (Ludovici 2008).

Nutrient status of the trees, as judged by foliar concentrations, was largely equivalent across the

327 treatments at year 20, despite some of the initial (year 5) separation in foliar N\% with OM removal.

328 Nutritional studies of these conifer species have consistently found strong correlations, of an

329 approximate two-fold range (e.g., 0.8 to 1.5\%), in foliar N\% with soil fertility (Kranabetter and Simard

3302008 , Lilles et al. 2014), so the most parsimonious interpretation of the LTSP foliar data is for little

331 change in $\mathrm{N}$ supply and uptake across treatments, even with the removal of over $50 \%$ of the site $\mathrm{N}$

332 capital through slash and forest floors. The increase in soil temperature of the mineral soil with forest

333 floor removal (Kranabetter and Chapman 2004) may have allowed earlier and deeper root egress, with

334 perhaps greater availability of $\mathrm{N}$ at depth, which could have compensated for $\mathrm{N}$ loss of the forest floor

335 itself (Prescott et al. 2000). Other key nutrients such as $\mathrm{Ca}, \mathrm{Mg}$ and $\mathrm{K}$ were considered vulnerable to

336 excessive losses by organic matter removal and compaction treatments (Arocena 2000), but as yet we

337 have found no foliar evidence of diminished cation availability. These findings are generally consistent

338 with much of the LTSP network in North America (e.g., Kabzems 2012, Holub et al. 2013, Curzon et al.

339 2014), although more significant OM removal effects have been found on sites with lower inherent soil

340 fertility or greater proportion of site nutrient capital in aboveground biomass (Wiebe et al. 2012, Hazlett

341 et al. 2014, Himes et al. 2014, Morris et al. 2014).

342 Strong discrimination against the ${ }^{15} \mathrm{~N}$ isotope, as demonstrated by $\delta^{15} \mathrm{~N}$ of approx. $-4 \%$ across

343 OM1C0 plots, is typical of ectomycorrhizal conifers (Craine et al. 2009), but the species effect suggests

344 interesting differences in some aspects of nitrogen nutrition. The reduced $\delta^{15} \mathrm{~N}$ values for pine may be

345 largely explained by the deeper rooting of pine compared to spruce, which would provide access to

346 more depleted ${ }^{15} \mathrm{~N}$ organic matter from lower in the soil profile (Houle et al. 2014). We have also found

347 young pine stands to be well colonized by Suillus tomentosus, a tuberculate ectomycorrhizal fungus with 
348

350

351

352

353

354

355

356

357

358

359

360

361

362

363

364

365

366

367

368

369

370

371 (e.g., Duan et al. 2009).

associated N-fixation (Chapman and Paul 2012) that may have contributed some amount of fixed-N with $\delta^{15} \mathrm{~N}$ values near $0 \%$. Differences in foliar \% $\mathrm{N}$ at year 20 suggests lodgepole pine may have a competitive advantage over spruce on mesic sub-boreal sites with relatively low soil $\mathrm{N}$ availability through these root-related adaptations. The significant effect of OM removal on foliar $\delta^{15} \mathrm{~N}$ for both species can be partly explained by the sharp difference in available rooting substrates $(4.44 \%$ for mineral soil and $0.54 \%$ for forest floor), which should narrow over time as forest floors re-establish. Mesic sub-boreal forests have a less severe summer drought than more southern LTSP locations, which could affect the sensitivity of foliar $\delta^{13} \mathrm{C}$ to soil moisture deficits (Gomez et al. 2002b, Tan et al. 2006). While species differences in $\Delta \delta^{13} \mathrm{C}$ were apparent, and matched the species interaction in growth increment to some degree, we conclude that the variation among study sites and typically subtle treatment effects (<1\%o change in enrichment; Gomez et al. 2002b) probably limited our ability to find a consistent influence of soil compaction or OM removal on C discrimination. The species interaction in $\delta^{13} \mathrm{C}$ regressions with tree biomass (at least for two of the test sites), however, along with the species differences in $\Delta \delta^{13} \mathrm{C}$ (spruce had more consistent gains in ${ }^{13} \mathrm{C}$ than pine, particularly where forest floors were retained), suggests some fruitful areas for future study. A number of field studies involving juvenile trees have reported both positive and negative relationships in $\delta^{13} \mathrm{C}$ with productivity, which Marguerit et al. (2014) attributed to specific physiological mechanisms; positive slopes in $\delta^{13} \mathrm{C}$ result from different assimilation rates of $\mathrm{CO}_{2}$, whereas negative slopes imply stomatal conductance as the limit to $\mathrm{CO}_{2}$ uptake. The improved photosynthetic capacity attributed to spruce by patterns in $\delta^{13} \mathrm{C}$ may be partly explained by concomitant increases in foliar N\%, although we found inconsistent relationships between these two traits across the study sites. An additional mechanism would possibly be an uplift in mesophyll conductance of $\mathrm{CO}_{2}$ with spruce (Warren 2008), in contrast to pine, on plots with large productivity gains due to favourable increases in soil moisture and temperature after soil disturbance 
373 partially overlapping niches along edaphic gradients (Coates et al. 2013), which we suggest would be

374 well aligned with the interactions found in this LTSP trial. Lodgepole pine is a shade-intolerant species

375 that dominates low fertility sites (dry, N-poor soils with thin forest floors) through adaptations such as

376 high water-use efficiency, deep rooting and associated N-fixation. White spruce (along with Abies) is a

377 shade-tolerant species with a high growth capacity, particularly on sites with rich, moist soils and well-

378 developed forest floors. Consistent with these realized niches are the significantly larger gains in tree

379 volume and foliar N\% for spruce and Abies compared to lodgepole pine along natural edaphic

productivity gradients (Kranabetter and Simard 2008, Lilles and Astrup 2012). The implication for forest management is that severe soil disturbances (forest floor scalping and compaction) has relegated site

382 suitability to only lodgepole pine, foregoing the opportunity to productively manage the other conifer species native to these mesic soils. This restriction in productive capacity may even extend beyond the current rotation if soil recovery continues to be slow (e.g., Walmsley et al. 2009). In this way the collective tree species response, where any member of the forest community has been negatively

386 impacted, can be considered a significant loss in site potential.

\section{Conclusions}

At twenty years post-treatment, both the losses and gains in productivity for hybrid white

389 spruce associated with organic matter removal and soil compaction greatly exceeded a 15\% threshold, 390 whereas no disturbance effects were detected on lodgepole pine. Foliar $\mathrm{N}$ and cation concentrations 391 were not reduced by OM removal for either species, despite the loss of over $50 \%$ of the site $\mathrm{N}$ capital in 392 slash and forest floors. Some key differences in species traits were suggested by foliar $\delta^{15} \mathrm{~N}$, attributed 393 to deeper rooting of pine, and a species interaction in foliar $\delta^{13} \mathrm{C}$ regressions with tree biomass, 394 indicating possibly higher $\mathrm{CO}_{2}$ assimilation potential for spruce. The results of this trial have implications 395 in assessing sustainable forestry through crop production, and as such we recommend a measure of 
396 collective tree species response, whereby a loss in site potential should be defined by a negative impact 397 on any member of the native forest community. 


\section{Acknowledgements}

We thank a number of individuals associated with the SBS LTSP, including Bill Chapman (BC

400 Ministry of Forests, Cariboo region) for installing and contributing data from the SBSdw site, along with

401 Rick Trowbridge, Anne Macadam, and Paul Sanborn for initiating the project, and a large number of

402 summer students and contractors assisting in all aspects of the study. In the most recent sampling

403 period this included Beth Woods, Shannon Elchuk, Kara Pitman, Eiji Matsuzakie, and Julia Kobetitch.

404 Clive Dawson and staff of the BC Ministry of Environment Analytical Laboratory undertook the soil and

405 foliar chemical analysis, while Dave Dunn and Rebecca Dixon of Natural Resources Canada (Pacific

406 Forestry Centre) contributed the $\mathrm{C}$ and $\mathrm{N}$ isotope abundance analysis. Peter Ott of the BC Ministry of

407 Forests was consulted on the statistical analysis. Funding for this project since the inception has been

408 through the British Columbia Ministry of Forests and Ministry of Environment. 
409

410

411

412

413

414

415

416

417

418

419

420

421

422

423

424

425

426

427

428

429

430

431

432

\section{References}

Achat, D.L., Deleuze, C., Landmann, G., Pousse, N., Ranger, J., and Augusto, L. 2015. Quantifying consequences of removing harvesting residues on forest soils and tree growth - A meta-analysis. For.

Ecol. Manage. 348: 124-141.

Ampoorter, E., De Freene, P., Hermy, M., and Verheyen, K. 2011. Effects of soil compaction on growth and survival of tree saplings: a meta-analysis. Basic App. Ecol. 12: 394-402.

Ares, A., Terry, T.A., Miller, R.E., Anderson, H.W., and Flaming, B.L. 2005. Ground-based forest harvesting effects on soil physical properties and Douglas-fir growth. Soil Sci. Soc. Am. J. 69: 1822-1832.

Arocena, J.M. 2000. Cations in solution from forest soils subjected to forest floor removal and compaction treatments. For. Ecol. Manage. 133: 71-80.

B.C. Ministry of Forests, 2004. SiteTools (ver. 3.3) [online]. Available from https://www.for.gov.bc.ca/hre/sitetool [accessed 20 Feb 2001].

Brais, S. 2001. Persistence of soil compaction and effects on seedling growth in northwestern Quebec.

Soil Sci. Soc. Am. J. 65: 1263-1271.

Brandtberg, P.O., and Olsson, B.A. 2012. Changes in the effects of whole-tree harvesting on soil chemistry during 10 years of stand development. For. Ecol. Manage. 277: 150-162.

Bulmer, C.E., and Simpson, D.G. 2005. Soil compaction and water content as factors affecting the growth of lodgepole pine seedlings on sandy clay loam soil. Can. J. Soil Sci. 85: 667-679.

Burger, J.A., Gray, G., and Scott, D.A. 2008. Using soil quality indicators for monitoring sustainable forest management. In Scientific Background for Soil Monitoring on National Forests and Rangelands:

Workshop Proceedings. Edited by D. Page-Dumroese, D. Neary and C. Trettin. Proc. RMRS-P-59, USDA, Rocky Mountain Research Station, CO. pp. 13-41.

Chapman, B.K., and Paul, L. 2012. Evidence that northern pioneering pines with tuberculate mycorrhizae are unaffected by varying soil nitrogen levels. Micro. Ecol. 64: 964-972. 
433 Choi, W.-J., Chang, S.X., Curran, M.P., Ro, H.-M., Kamaluddin, M., and Zwiazek, J.J. 2005. Foliar $\delta^{13} \mathrm{C}$ and $434 \quad \delta^{15} \mathrm{~N}$ response of lodgepole pine and Douglas-fir seedlings to soil compaction and forest floor removal. 435 For. Sci. 51: 546-555.

436 Coates, K.D., Lilles, E.B., and Astrup, R. 2013. Competitive interactions across a soil fertility gradient in a 437 multispecies forest. J. Ecol. 101: 806-818.

438 Craine, J.M., Elmore, A.J., Aidar, M.P.M., Bustamante, M., Dawson, T.E., Hobbie, E.A., Kahmen, A., Mack, 439 M.C., McLauchlan, K.K., Michelsen, A., Nardoto, G.B., Pardo, L.H., Peñuelas, J., Reich, P.B., Schuur, E.A.G., 440 Stock, W.D., Templer, P.H., Virginia, R.A., Welker, J.M., and Wright, I.J. 2009. Global patterns of foliar 441 nitrogen isotopes and their relationships with climate, mycorrhizal fungi, foliar nutrient concentrations, 442 and nitrogen availability. New Phyt. 183: 980-992.

443 Curran, M.P., Maynard, D.G., Heninger, R.L., Terry, T.A., Howes, S.W., Stone, D.M., Niemann, T., Miller, 444 R.D., and Powers, R.F. 2005. An adaptive management process for forest soil conservation. For. Chron. $445 \quad 81: 717-722$.

446 Curzon M.T., D’Amato, A.W., and Palik, B.J. 2014. Harvest residue removal and soil compaction impact 447 forest productivity and recovery: Potential implications for bioenergy harvests. For. Ecol. Manage. 329: $448 \quad 99-107$.

449 Dawson, T.E., Mambelli, S., Plamboeck, A.H., Templer, P.H., and Tu, K.P. 2002. Stable isotopes in plant 450 ecology. Ann. Rev. Ecol. Sys. 33: 507-559.

451 Duan, B., Li, Y., Zhang, X., Korpelainen, H., and Li, C. 2009. Water deficit affects mesophyll limitation of 452 leaves more strongly in sun than in shade in two contrasting Picea asperata populations. Tree Phys. 29: $453 \quad 1551-1561$.

454 Duchesne, L., and Houle, D. 2008. Impact of nutrient removal through harvesting on the sustainability of 455 the boreal forest. Ecol. Appl. 18: 1642-1651. 
Egnell, G. 2011. Is the productivity decline in Norway spruce following whole-tree harvesting in the final

457 felling in boreal Sweden permanent or temporary? For.Ecol. Manage. 261: 148-153.

458 Eis, S., Craigdallie, D., and Simmons, C. 1982. Growth of lodgepole pine and white spruce in the interior 459 of British Columbia. Can. J. For. Res. 12: 567-575.

460 Fleming, R.L., Foster, N.W., Jeglum, J.K., and Hazlett, P.W. 1998. Soil compaction and sustainable 461 productivity on coarse-textured jack pine sites. In Developing Systems for Integrating Bioenergy into 462 Environmentally Sustainable Forestry. Edited by A.T. Lowe and C.T. Smith. IEA Bioenergy Agreement 463 Task 18 Workshop, New Zealand Forest Research Institute, Rotorua. pp. 72-81.

464 Fleming, R.L., Leblanc, J.-D., Hazlett, P.W., Weldon, T., Irwin, R., and Mossa, D.S. 2014. Effects of biomass 465 harvest intensity and soil disturbance on jack pine stand productivity: 15-year results. Can. J. For. Res.

44: 1566-1574.

467 Gomez, A., Powers, R.F., Singer, M.J., and Horwath, W.R. 2002a. Soil compaction effects on growth of 468 young Ponderosa pine following litter removal in California's Sierra Nevada. Soil Sci. Soc. Am. J. 66: $469 \quad 1334-1343$.

470 Gomez, A., Singer, M.J., Powers, R.F., and Horwath, W.R. 2002b. Soil compaction effects on water status 471 of ponderosa pine assessed through ${ }^{13} \mathrm{C} /{ }^{12} \mathrm{C}$ composition. Tree Phys. 22: 459-467.

472 Hazlett, P.W., Morris, D.M., and Fleming, R.L. 2014. Effects of biomass removals on site carbon and 473 nutrients and Jack pine growth in boreal forests. Soil Sci. Soc. Am. J. 78: 183-195.

474 Helmisaari, H.-S., Hanssen, K.H., Jacobson, S., Kukkola, M., Luiro, J., Saarsalmi, A., Tamminen, P., Tveite, 475 B. 2011. Logging residue removal after thinning in Nordic boreal forests: long-term impact on tree 476 growth. For. Ecol. Manage. 261: 1919-1927.

477 Heninger, R., Scott, W., Dobkowski, A., Miller, R., Anderson, H., and Duke, S. 2002. Soil disturbance and 478 10-year growth response of coast Douglas-fir on nontilled and tilled skid trails in the Oregon Cascades.

479 Can. J. For. Res. 32: 233-246. 
480 Himes, A.J., Turnblom, E.C., Harrison, R.B., Littke, K.M., Devine, W.D., Zabowski, D., and Briggs, D.G. 481 2014. Predicting risk of long-term nitrogen depletion under whole-tree harvesting in the Coastal Pacific 482 Northwest. For. Sci. 60: 382-390.

483 Holub, S.M., Terry, T.A., Harrington, C.A., Harrison, R.B., and Meade, R. 2013. Tree growth ten years 484 after residual biomass removal, soil compaction, tillage, and competing vegetation control in a highly485 productive Douglas-fir plantation. For. Ecol. Manage. 305: 60-66.

486 Houle, D., Moore, J.-D., Ouimet, R., Marty, C. 2014 Tree species partition N uptake by soil depth in 487 boreal forests. Ecology 95: 1127-1133.

488 Kabzems, R. 2012. Aspen and white spruce productivity is reduced by organic matter removal and soil 489 compaction. For. Chron. 88: 306-316.

490 Kalra, Y.P., and Maynard, D.G. 1991. Methods Manual for Forest Soil and Plant Analysis. Information 491 Report NOR-X-319. Forestry Canada, Edmonton, AB. 116 p.

492 Kovats, M. 1977. Estimating juvenile tree volumes for provenance and progeny testing. Can. J. For. Res.

493 7: 335-342.

494 Kranabetter, J.M., and Chapman, B.K. 2004. An analysis of litter nitrogen dynamics using artificial soils 495 across a gradient of forest soil disturbances. Can. J. Soil Sci. 84: 159-167.

496 Kranabetter, J.M., Sanborn, P., Chapman, B.K., and Dube, S. 2006. The contrasting response to soil 497 disturbance between lodgepole pine and hybrid white spruce in subboreal forests. Soil Sci. Soc. Am. J.

498 70: 1591-1599.

499 Kranabetter, J.M., and Simard, S.W. 2008. Inverse relationship between understory light and foliar 500 nitrogen along productivity gradients of boreal forests. Can. J. For. Res. 38: 2487-2496.

501 Krzic, M., Bulmer, C.E., Teste, F., Dampier, L., and Rahman, S. 2004. Soil properties influencing 502 compactability of forest soils in British Columbia. Can. J. Soil Sci. 84: 219-226. 
503 Lilles, E.B., and Astrup, R. 2012. Multiple resource limitation and ontogeny combined: a growth rate

504 comparison of three co-occurring conifers. Can. J. For. Res. 42: 99-110.

505 Lilles, E.B., Astrup, R., Lefrançois, M.-L., and Coates, K.D. 2014. Sapling leaf trait responses to light, tree

506 height and soil nutrients for three conifer species of contrasting shade tolerance. Tree Phys. 34: 1334-

5071347.

508 Ludovici, K.H. 2008. Compacting Coastal Plain soils changes midrotation loblolly pine allometry by

509 reducing root biomass. Can. J. For. Res. 38: 2169-2176.

510 Marguerit, E., Bouffier, L., Chancerel, E., Costa, P., Lagane, F., Guehl, J.-M., Plomion, C., and Brendel, O.

511 2014. The genetics of water-use efficiency and its relation to growth in maritime pine. J. Exp. Bot. 65:

$512 \quad 4757-4768$.

513 Meidinger, D., and Pojar, J. 1991. Ecosystems of British Columbia, Crown Publications, Victoria, BC. 330

514 p.

515 Moffat, A.J. 2003. Indicators of soil quality for UK forestry. Forestry 76: 547-568.

516 Montgomery, D.C. 2008. Design and Analysis of Experiments, Seventh Edition. John Wiley \& Sons. New

517 York. 688 p.

518 Morris, D.M. 1997. The role of long-term site productivity in maintaining healthy ecosystems: a

519 prerequisite of ecosystem management. For. Chron. 73: 731-740.

520 Morris, D.M., Kwiaton, M.M., and Duckert, D.R. 2014. Black spruce growth response to varying levels of

521 biomass harvest intensity across a range of soil types: 15-year results. Can. J. For. Res. 44: 313-325.

522 Nambiar, E.K.S. 1996. Sustained productivity of forests is a continuing challenge to soil science. Soil Sci.

523 Soc. Am. J. 60: 1629-1642.

524 Page-Dumroese, D., Jurgensen, M., Elliot, W., Rice, T., Nesser, J., Collins, T., and Meurisse, R. 2000 Soil

525 quality standards and guidelines for forest sustainability in northwestern North America. For. Ecol.

526 Manage. 138: 445-462. 
527 Paré, D., Rochon, P., and Brais, S. 2002. Assessing the geochemical balance of managed boreal forests.

528 Ecol. Ind. 1: 293-311.

529 Paul, D., Skrzypek, G., and Fórizs, I. 2007. Normalization of measured stable isotopic compositions to

530 isotope reference scales - a review. Rapid Commun. Mass Spectrom. 21: 3006-3014.

531 Ponder Jr., F., Fleming, R.L., Berch, S., Busse, M.D., Elioff, J.D., Hazlett, P.W., Kabzems, R.D., Kranabetter, 532 J.M., Morris, D.M., Page-Dumroese, D., Palik, B.J., Powers, R.F., Sanchez, F.G., Scott, D.A., Stagg, R.H., 533 Stone, D.M., Young, D.H., Zhang, J., Ludovici, K.H., McKenney, D.W., Mossa, D.S., Sanborn, P.T., and

534 Voldseth, R.A. 2012 Effects of organic matter removal, soil compaction and vegetation control on 10th

535 year biomass and foliar nutrition: LTSP continent-wide comparisons. For. Ecol. Manage. 278: 35-54.

536 Powers, R.F. 2006. Long-Term Soil Productivity: genesis of the concept and principles behind the 537 program. Can. J. For. Res. 36: 519-528.

538 Powers, R.F., Scott, D.A., Sanchez, F.G., Voldseth, R.A., Page-Dumroese, D., Elioff, J.D., and Stone, D.M. 539 2005. The North American long-term soil productivity experiment: findings from the first decade of 540 research. For. Ecol. Manage. 220: 31-50.

541 Powers, R.F., Tiarks, A.E., and Boyle, J.R. 1999. Assessing soil quality: practicable standards for 542 sustainable forest productivity in the United States. In The Contribution of Soil Science to the 543 Development of and Implementation of Criteria and Indicators of Sustainable Forest Management.

544 Edited by E.A. Davidson. SSSA Special Publication 53. pp 53-80.

545 Prescott, C.E., Maynard, D.G., and Laiho, R. 2000. Humus in northern forests: friend or foe? For. Ecol. 546 Manage. 133: 23-36.

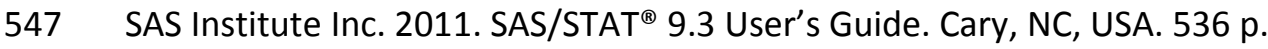

548 Sanborn P., Kranabetter J.M., and Chapman, B. 2000. Nutrient removals in woody biomass: preliminary 549 estimates from the Sub-Boreal Long-Term Soil Productivity study. LTSP Research Note 04, BC Forest 
550 Service [online]. Available from https://www.for.gov.bc.ca/hfd/pubs/docs/Itsps/Rrn004.htm [accessed

55117 Dec 2008].

552 Schoenholtz, S.H., Van Miegroet, H., and Burger, J.A. 2000. A review of chemical and physical properties

553 as indicators of forest soil quality: challenges and opportunities. For. Ecol. Manage. 138: 335-356.

554 Scott, D.A., Eaton, R.J., Foote, J.A., Vierra, B., Boutton, T.W., Blank, G.B., and Johnsen, K. 2014. Soil

555 ecosystem services in loblolly pine plantations 15 years after harvest, compaction, and vegetation

556 control. Soil Sci. Soc. Am. J. 78: 2032-2040.

557 Startsev, A.D., and McNabb, D.H. 2009. Effects of compaction on aeration and morphology of boreal

558 forest soils in Alberta, Canada. Can. J. Soil Sci. 89: 45-56.

559 Stone, D.M., and Kabzems, R. 2002. Aspen development on similar soils in Minnesota and British

560 Columbia after compaction and forest floor removal. For. Chron. 78: 886-891.

561 Tan, X., Kabzems, R., and Chang, S.X. 2006. Response of forest vegetation and foliar $\delta^{13} \mathrm{C}$ and $\delta^{15} \mathrm{~N}$ to soil

562 compaction and forest floor removal in a boreal aspen forest. For. Ecol. Manage. 222: 450-458.

563 Thiffault, E., Bélanger, N., Paré, D., and Munson, A.D. 2007. How do forest harvesting methods compare

564 with wildfire? A case study of soil chemistry and tree nutrition in the boreal forest. Can. J. For. Res. 37:

$565 \quad 1658-1668$.

566 Thiffault, E., Hannam, K.D., Paré, D., Titus, B.D., Hazlett, P.W., Maynard, D.G., and Brais, S. 2011. Effects

567 of forest biomass harvesting on soil productivity in boreal and temperate forests - A review. Environ.

568 Rev. 19: 278-309.

569 Walmsley, J.D., Jones, D.L., Reynolds, B., Price, M.H., and Healey, J.R. 2009. Whole tree harvesting can

570 reduce second rotation forest productivity. For. Ecol. Manage. 257: 1104-1111.

571 Wang, G.G. 1998. An ecologically based model for site index conversion among species. Can. J. For. Res.

$572 \quad$ 28: $234-238$. 
573 Wang, T., Hamann, A., Spittlehouse, D.L., and Aitken. S.N. 2006. Development of scale-free climate data

574 for western Canada for use in resource management. Int. J. Climatology 26: 383-397.

575 Warren, C.R. 2008. Stand aside stomata, another actor deserves centre stage: the forgotten role of the 576 internal conductance to $\mathrm{CO}_{2}$ transfer. J. of Exp. Bot. 59: 1475-1487.

577 Wiebe, S., Morris, D., Luckai, N., and Reid, D. 2012. Coarse woody debris dynamics following biomass

578 harvesting: tracking carbon and nitrogen patterns during early stand development in upland black

579 spruce ecosystems. Int. J. For. Eng. 23: 25-32.

580 Zhao, Y., Krzic, M., Bulmer, C.E., Schmidt, M.G., and Simard, S.W. 2010. Relative bulk density as a

581 measure of compaction and its influence on tree height. Can. J. For. Res. 40: 1724-1735. 
582 Table 1. Survival, height, and stem diameter for lodgepole pine and hybrid white spruce at year 20 post-

583 treatment (average of 3 sites, SE in brackets).

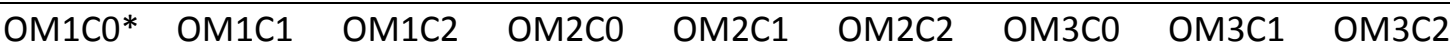

\begin{tabular}{llllllllll}
\hline Pine & & & & & & & & & \\
Survival & 90 & 86 & 89 & 86 & 87 & 90 & 93 & 90 & 88 \\
$(\%)$ & $(3.7)$ & $(4.3)$ & $(4.9)$ & $(5.2)$ & $(6.4)$ & $(3.8)$ & $(3.2)$ & $(3.2)$ & $(1.9)$ \\
Height & 6.35 & 6.82 & 6.64 & 6.95 & 6.63 & 6.61 & 7.04 & 6.59 & 6.75 \\
$(\mathrm{~m})$ & $(0.10)$ & $(0.11)$ & $(0.11)$ & $(0.13)$ & $(0.12)$ & $(0.10)$ & $(0.13)$ & $(0.11)$ & $(0.10)$ \\
DBH & 9.6 & 10.3 & 10.5 & 10.6 & 10.7 & 10.3 & 10.9 & 10.0 & 10.4 \\
$(\mathrm{~cm})$ & $(0.2)$ & $(0.2)$ & $(0.2)$ & $(0.2)$ & $(0.2)$ & $(0.2)$ & $(0.3)$ & $(0.2)$ & $(0.2)$
\end{tabular}

Spruce

$\begin{array}{llllllllll}\begin{array}{l}\text { Survival } \\ \text { (\%) }\end{array} & 94 & 89 & 87 & 95 & 86 & 88 & 95 & 83 & 96 \\ & (3.2) & (1.2) & (4.0) & (4.2) & (6.2) & (9.7) & (0.6) & (15.5) & (1.2) \\ \text { Height } & 3.46 & 3.38 & 3.97 & 3.31 & 3.96 & 3.83 & 3.14 & 3.03 & 2.56 \\ \text { (m) } & (0.9) & (0.9) & (0.9) & (0.9) & (1.3) & (1.1) & (1.1) & (0.9) & (0.8) \\ & & & & & & & & & \\ \text { RCD* } & 7.1 & 7.1 & 8.2 & 7.0 & 8.5 & 8.1 & 7.4 & 6.9 & 5.9 \\ (\mathrm{~cm}) & (0.2) & (0.2) & (0.3) & (0.2) & (0.4) & (0.3) & (0.3) & (0.2) & (0.2)\end{array}$

584 *OM1 = bole-only removal; $\mathrm{OM} 2$ = whole-tree harvest; $\mathrm{OM} 3=$ scalped to mineral soil; $\mathrm{C} 0$ = no compaction; $\mathrm{C} 1=$ 585 light compaction; $\mathrm{C} 2$ = heavy compaction. Spruce diameter measured at root collar, rather than $1.3 \mathrm{~m}$, because of 586 shorter stature 
587 Table 2. Statistical significance ( $p$ values $<0.10$ in bold) of organic matter removal, compaction and tree species on survival, percent change in 588 bole volume increment (\% $\Delta$ vol inc) and foliar attributes of lodgepole pine and white spruce at year 20 post-treatment.

\begin{tabular}{lccccccc}
\hline Treatment variable & Num DF* & Den DF & Survival & $\% \Delta$ vol inc & Foliar $\mathrm{N} \%$ & Foliar $\delta^{15} \mathrm{~N}$ & $\Delta$ Foliar $\delta^{13} \mathrm{C}$ \\
\hline OM removal & 2 & 14 & 0.878 & $\mathbf{0 . 0 4 8}$ & 0.445 & $<\mathbf{0 . 0 0 1}$ & $\mathbf{0 . 0 2 1}$ \\
Compaction & 2 & 14 & 0.147 & 0.238 & 0.173 & 0.781 & 0.896 \\
OM $\times$ Comp & 3 & 14 & 0.940 & 0.205 & 0.601 & 0.251 & 0.847 \\
Species & 1 & 16 & 0.133 & 0.169 & $\mathbf{0 . 0 0 2}$ & $<\mathbf{0 . 0 0 1}$ & $\mathbf{0 . 0 0 1}$ \\
OM $\times$ Species & 2 & 16 & 0.860 & $\mathbf{0 . 0 0 3}$ & 0.924 & 0.755 & 0.462 \\
Comp $\times$ Species & 2 & 16 & 0.134 & 0.361 & 0.947 & 0.756 & 0.512 \\
OM $\times$ Comp $\times$ Species & 3 & 16 & 0.471 & $\mathbf{0 . 0 9 9}$ & 0.431 & 0.361 & 0.232
\end{tabular}


591 Table 3. Statistical significance ( $p$ values $<0.10$ in bold) of organic matter removal, compaction and tree

592 species on foliar macronutrient concentrations and needle mass at year 20 for lodgepole pine and white 593 spruce (mean of 3 sites, SE in brackets). Degrees of freedom for the statistical model as shown in Table 5942.

\begin{tabular}{lllllll}
\hline Tree species & $\mathrm{P}$ & $\mathrm{S}$ & $\mathrm{Ca}$ & $\mathrm{K}$ & $\mathrm{Mg}$ & Mass \\
& $(\%)$ & $(\%)$ & $(\%)$ & $(\%)$ & $(\%)$ & $(\mathrm{g})$ \\
\hline Lodgepole pine & 0.12 & 0.080 & 0.22 & 0.42 & 0.12 & 1.88 \\
& $(0.001)$ & $(0.001)$ & $(0.005)$ & $(0.006)$ & $(0.007)$ & $(0.08)$ \\
White spruce & 0.18 & 0.077 & 0.45 & 0.59 & 0.10 & 0.56 \\
& $(0.005)$ & $(0.002)$ & $(0.017)$ & $(0.009)$ & $(0.004)$ & $(0.01)$ \\
Treatment $p$ value & & & & & & \\
OM removal & 0.549 & $<0.001$ & 0.442 & 0.275 & 0.466 & 0.994 \\
Compaction & 0.127 & $<0.001$ & 0.917 & 0.005 & 0.972 & 0.789 \\
OM $\times$ Comp & 0.663 & 0.109 & 0.776 & 0.882 & 0.813 & 0.995 \\
Species & $<0.001$ & $\mathbf{0 . 0 6 9}$ & $<0.001$ & $\mathbf{0 . 0 0 1}$ & $<0.001$ & $<0.001$ \\
\hline
\end{tabular}


597 Figure 1. Gravimetric moisture content of the mineral soil for OM removal treatments, SBSmc site only, 598 during the 2015 growing season (May 15 to Sept 17; mean of 3 compaction treatments per data point).

599 Figure 2. Bole volume increment between years 15 and 20 for lodgepole pine and white spruce in 600 relation to the least disturbed plot (OM1C0) (mean of 3 sites, SE as bars). OM1 = bole-only removal;

$601 \mathrm{OM} 2$ = whole-tree harvest; $\mathrm{OM} 3$ = scalped to mineral soil; $\mathrm{CO}$ = no compaction; $\mathrm{C} 1$ = light compaction;

$602 \quad C 2=$ heavy compaction.

603 Figure 3. Average foliar $\mathrm{N}$ concentrations by OM removal treatments between years 5 and 20 post-

604 treatment for a) lodgepole pine and b) white spruce (each marker the mean of 3 sites and 3 compaction 605 treatments, $n=9, \mathrm{SE}$ as bars).

606 Figure 4. Average foliar $\delta^{15} \mathrm{~N}(\% \circ)$ by tree species and OM removal treatments (each bar the mean of 3

607 sites and 3 compaction treatments, $n=9$, SE as bars).

608 Figure 5. Average difference in foliar $\delta^{13} \mathrm{C}$ by tree species and $\mathrm{OM}$ removal treatments in relation to the 609 least disturbed plot (OM1C0) (mean of 3 sites and 3 compaction treatments [ $=9]$, with the exception 610 of stem only [ $n=6]$, SE as bars).

611 Figure 6. Plot mean of foliar $\delta^{13} \mathrm{C}(\%)$ in correlation with tree bole volume $\left(\mathrm{dm}^{3}\right)$, by site, for a) lodgepole 612 pine and b) white spruce. Species $\times \delta^{13} \mathrm{C}$ interaction $p$ value $=0.057$ for SBSwk, 0.027 for SBSmc, and $613 \quad 0.161$ for SBSdw. 


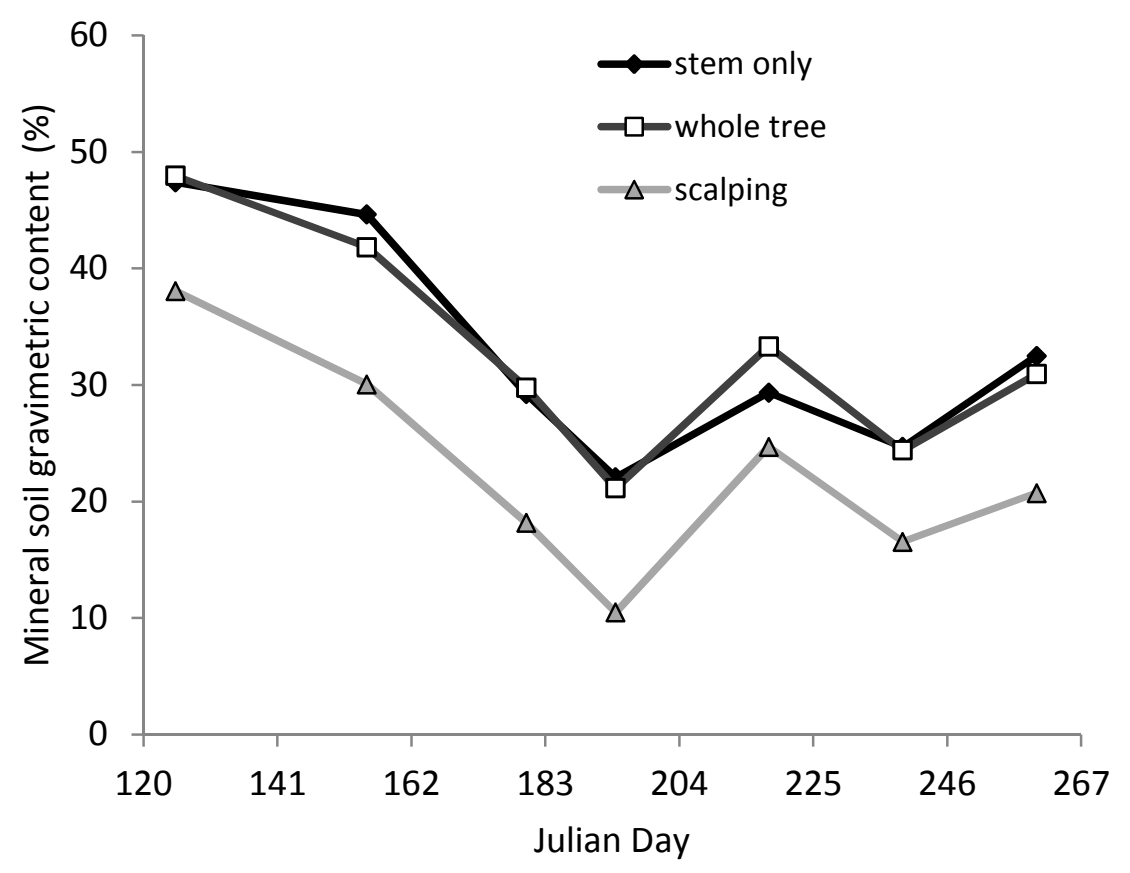

615

616

617

618

625

626

627

628

Fig. 1 


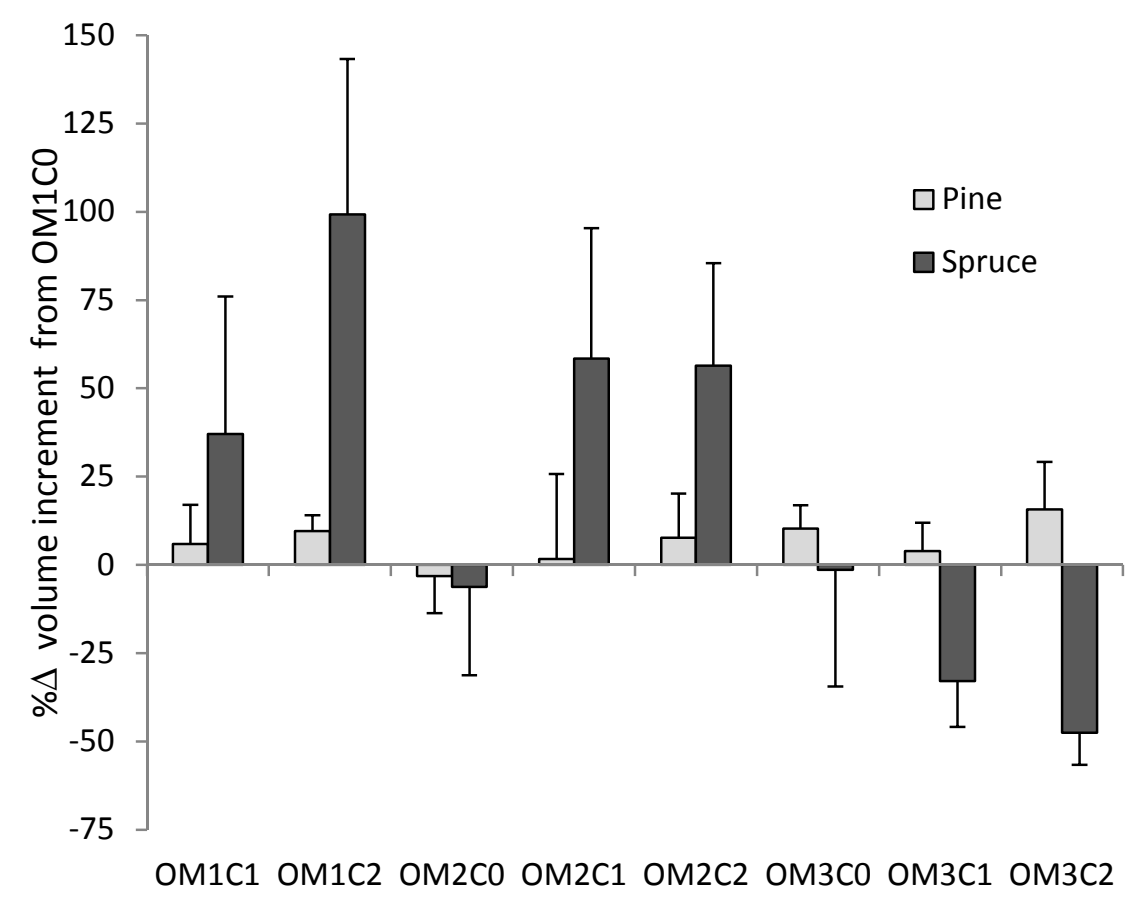

630

631

632

633

634

635

636

637

638

639

640

641

642

643

644

645 Fig. 2

646 

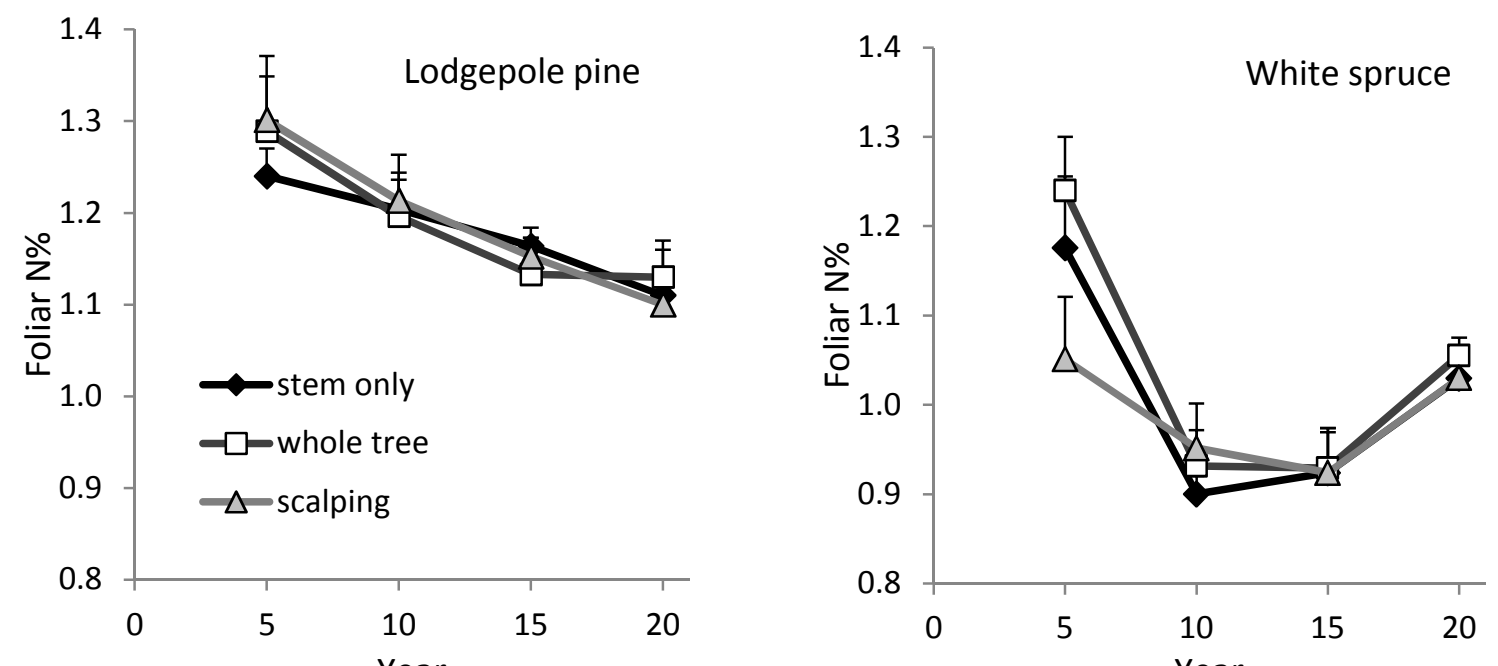

647 a)

Year

b)

Year

648

649

650

651

652

653

654

655

656

657

658

$659 \quad$ Fig. 3

660 


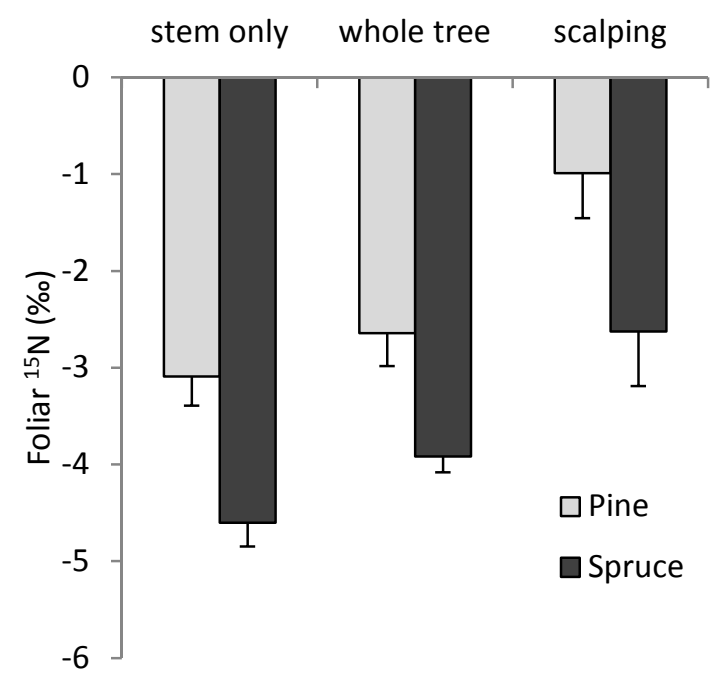

662

663

664

665

666

667

668

669

670

671

672

$673 \quad$ Fig. 4

674

https://mc06.manuscriptcentral.com/cjfr-pubs 


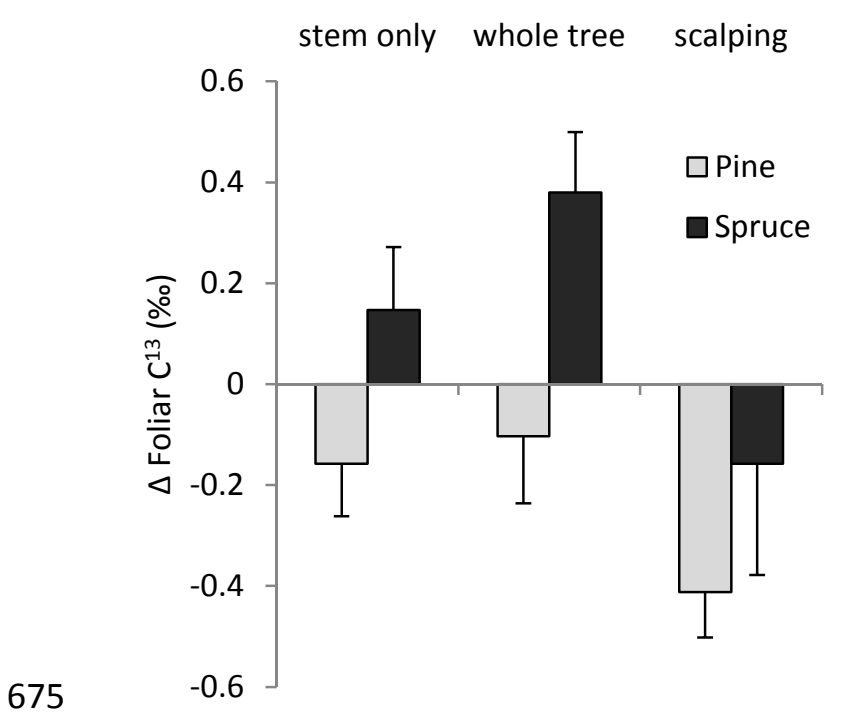

676

677

678

679

680

681

682

683

684

685

686

687

$688 \quad$ Fig. 5

689

https://mc06.manuscriptcentral.com/cjfr-pubs 

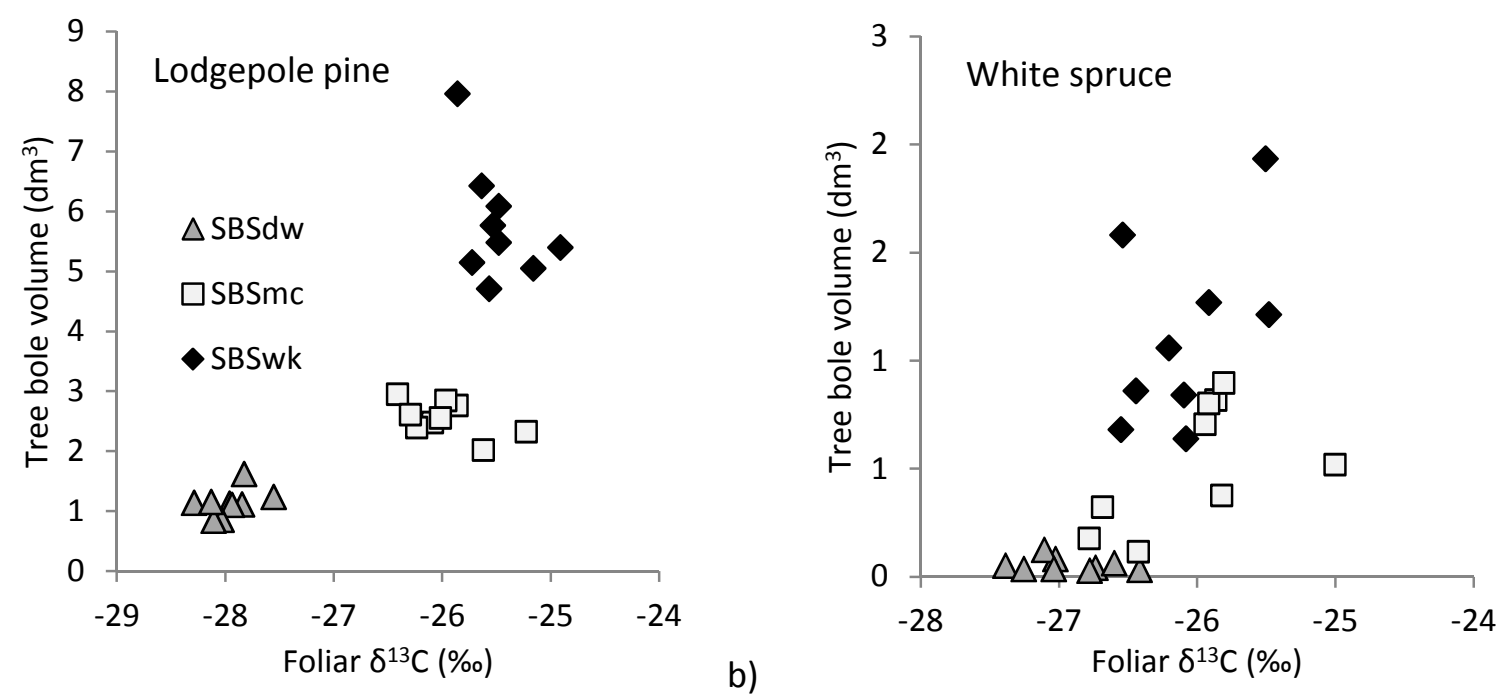

690

a)

b)

691

692

693

694

695

696

697

698

699

700

701

702

703

704

705

706

Fig. 6 
An investigation into the contrasting growth response of lodgepole pine and white spruce to harvest-related soil disturbance

\section{J.M. Kranabetter, S. Dube, and E.B. Lilles}

Supplementary Fig. S1. Foliar sulphur (S) concentrations by pine and spruce across ( $a$ ) organic matter removal and $(b)$ compaction treatments; $(c)$ foliar potassium $(\mathrm{K})$ concentrations by pine and spruce across compaction treatments. 

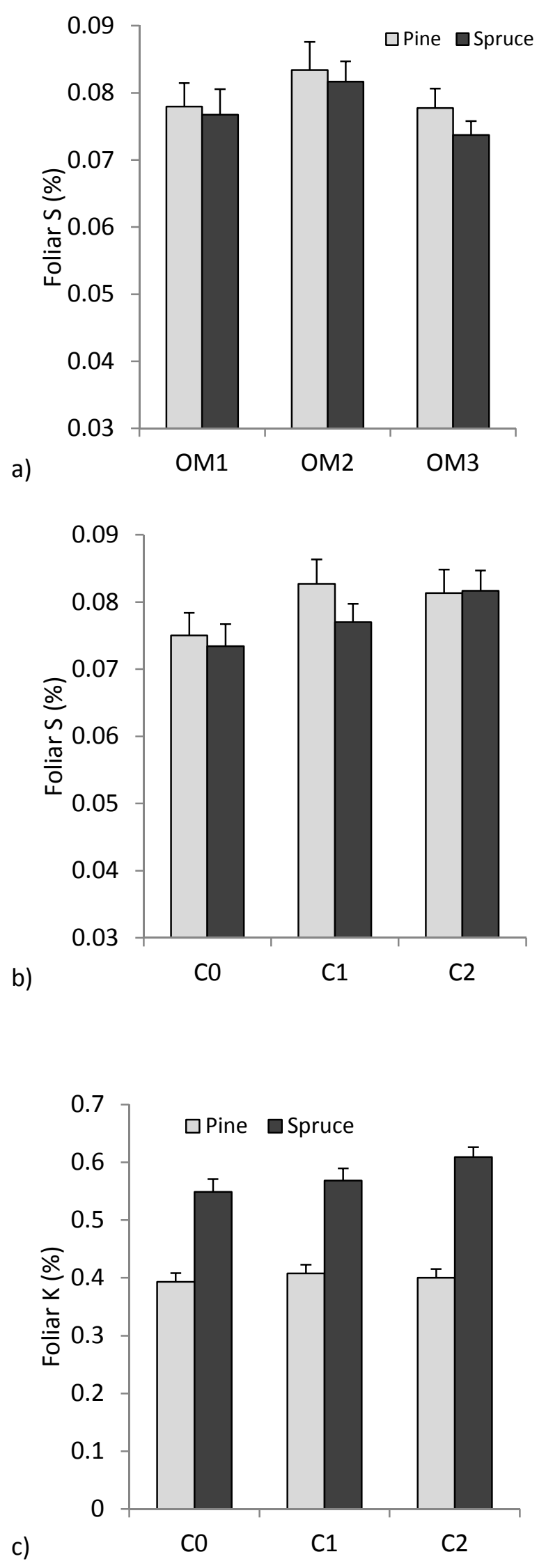

https://mc06.manuscriptcentral.com/cjfr-pubs 